\title{
Correction to: Isolation and identification of Bacillus thuringiensis strains native of the Eastern Province of Saudi Arabia
}

Amina A. Hassan ${ }^{1,2}$, Mohamed A. Youssef ${ }^{2}$, M. M. A. Elashtokhy², I. M. Ismail ${ }^{3}$, Munirah Aldayel ${ }^{1}$ and Eman Afkar ${ }^{4,5^{*}}$

\section{Correction to: Egypt J Biol Pest Control 31, 6 (2021)}

https://doi.org/10.1186/s41938-020-00352-8

Following publication of the original article (Hassan et al., 2021), it came to the authors' attention that affiliation 3 had been omitted from the affiliation details of the article.

The affiliations in the original article have since been corrected.

Moreover, the correct affiliation details may be seen in this correction.

\section{Author details}

'Department of Biological Sciences, College of Science, King Faisal University, P.O Box 31892, Al Hofuf, Al-Ahsa, Saudi Arabia. ${ }^{2}$ Genetics Department, College of Agriculture, Zagazig University, Zagazig, Egypt. ${ }^{3}$ Department of Microbial Molecular Biology, Agricultural Genetic Engineering Research Institute (AGERI), Agricultural Research Center (ARC), Giza Postal Code, 12619, Egypt. ${ }^{4}$ Preparatory Year Deanship, King Faisal University, P.O Box 31892, Al Hofuf, Al-Ahsa, Saudi Arabia. ${ }^{5}$ Department of Botany and Microbiology, College of Science, Bani-Suef University, Beni Suef, Egypt.

Published online: 03 February 2021

\section{Reference}

Hassan AA, Youssef MA, Elashtokhy MMA et al (2021) Isolation and identification of Bacillus thuringiensis strains native of the Eastern Province of Saudi Arabia.

Egypt J Biol Pest Control 31:6 https://doi.org/10.1186/s41938-020-00352-8

\author{
The original article can be found online at https://doi.org/10.1186/s41938- \\ 020-00352-8. \\ * Correspondence: eafkar@kfu.edu.sa \\ ${ }^{4}$ Preparatory Year Deanship, King Faisal University, P.O Box 31892, Al Hofuf, \\ Al-Ahsa, Saudi Arabia \\ ${ }^{5}$ Department of Botany and Microbiology, College of Science, Bani-Suef \\ University, Beni Suef, Egypt \\ Full list of author information is available at the end of the article
}

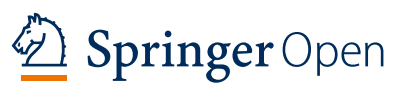

(c) The Author(s). 2021 Open Access This article is licensed under a Creative Commons Attribution 4.0 International License, which permits use, sharing, adaptation, distribution and reproduction in any medium or format, as long as you give appropriate credit to the original author(s) and the source, provide a link to the Creative Commons licence, and indicate if changes were made. The images or other third party material in this article are included in the article's Creative Commons licence, unless indicated otherwise in a credit line to the material. If material is not included in the article's Creative Commons licence and your intended use is not permitted by statutory regulation or exceeds the permitted use, you will need to obtain permission directly from the copyright holder. To view a copy of this licence, visit http://creativecommons.org/licenses/by/4.0/. 